\title{
Can pesticides, copper and seasonal water temperature explain the seagrass Zostera noltei decline in the Arcachon bay?
}

\author{
Gamain Perrine ${ }^{1}$, Feurtet-Mazel Agnès ${ }^{1}$, Maury-Brachet Régine ${ }^{1}$, Auby Isabelle ${ }^{3}$, Pierron Fabien ${ }^{1}$, \\ Belles Angel ${ }^{2}$, Budzinski Hélène ${ }^{2}$, Daffe Guillemine ${ }^{1}$, Gonzalez Patrice ${ }^{1,{ }^{*}}$
}

${ }^{1}$ Univ. Bordeaux, UMR EPOC CNRS 5805, Aquatic ecotoxicology team, 33120 Arcachon, France

${ }^{2}$ Univ. Bordeaux, UMR EPOC CNRS 5805, LPTC team, 33615 Pessac, France

${ }^{3}$ IFREMER Arcachon, Laboratoire Environnement Ressources, Quai du Cdt Silhouette, 33120 Arcachon, France

*Corresponding author : Patrice Gonzales, email address : Patrice.gonzalez@u-bordeaux.fr

\begin{abstract}
:
Dwarf eelgrasses (Zostera noltei) populations have decreased since 2005 in Arcachon Bay (southwest France). Various stressors have been pointed out, however the role of xenobiotics like pesticides or copper $(\mathrm{Cu})$ and of parameters like water temperature warming have not yet been explored. To determine their impact, $Z$. noltei individuals were collected in a pollution-free site and transferred to the laboratory in seawater microcosms. This dwarf eelgrass was exposed to a pesticide cocktail and copper, alone or simultaneously, at temperatures $\left(10^{\circ} \mathrm{C}, 20^{\circ} \mathrm{C}, 28^{\circ} \mathrm{C}\right)$ representative of different seasons. After a two-week contamination, leaf growth, leaf bioaccumulation of $\mathrm{Cu}$, and differential expression of target genes were studied. Eelgrasses bioaccumulated Cu regardless of the temperature, with reduced efficiency in the presence of the $\mathrm{Cu}$ and pesticide cocktail at the two higher temperatures. High temperature also exacerbated the effect of contaminants, leading to growth inhibition and differential gene expression. Mitochondrial activity was strongly impacted and higher mortality rates occurred. Experimental results have been confirmed during field survey. This is the first report on the impacts on $Z$. noltei of pesticides and $\mathrm{Cu}$ associate to temperature.
\end{abstract}

\section{Highlights}

Zostera noltei decline in the Arcachon Bay (southwest France) Molecular effects of Copper and Pesticides cocktail used alone or mixed $-\mathrm{Cu}$ and Pesticides decreased the mitochondrial metabolism and photosynthesis

Keywords : Zostera noltei, Arcachon Bay, Pesticides, Copper, Cellular impacts 


\section{I - Introduction}

Arcachon Bay is one of the most iconic coastal area in southwest France, in part because of its size and the biological diversity of its environment. This interface between ocean, continent and atmosphere is also the location of many economic activities such as oyster farming, fishing, and water sports, supporting the local economy. Agricultural production (mainly corn) is also active on its watershed, and close to the Bay industrial activities are developing for a growing population. This high anthropic pressure is leading to increased chemical pollution in the Bay.

Among xenobiotics identified in the water column, pesticides consisting mainly of herbicides were determined in significant concentrations and have been therefore followed for a decade (Auby and Maurer, 2004; Auby et al., 2007; Auby et al. 2011). Indeed, the Leyre tributary is considered the major input of agriculture used pesticides in Arcachon Bay, responsible for more than $90 \%$ of the total pesticides (REPAR report, 2010) with a majority of S-metolachlor, acetochlor and their metabolites.In addition, some contaminants originate from leaching of biocides from boats coated with antifouling paints. Copper $(\mathrm{Cu})$ is also widely found due to its common use as fungicide and bactericide. Indeed, $\mathrm{Cu}$ is the major component of antifouling paints $(3000-5000 \mathrm{Kg} \mathrm{Cu} /$ year) used on boats in the bay, (Auby and Maurer, 2004). Thus, there is growing anthropogenic pressure which can disturb the ecological balance of this system.

Arcachon Bay is characterized by the presence of the largest dwarf eelgrass (Zostera noltei) beds in Europe. Dwarf eelgrass, Z. noltei, is a marine phanerogam species (Zosteraceae family) which colonizes intertidal zones, and develops in large beds (Kuo and Den Hartog, 2006). It has an ecological, economical and patrimonial interest because i) it is an indicator of disturbance and development of the coastal area, ii) of its protective role in offering areas for spawning and nursery, and iii) of its underwater landscape value (Auby et al. 2010). It undergoes temperature variations at each tide as well as seasonal variations. Biomass variations follow a unimodal pattern, with a maximum in summer and minimum in winter, mainly based on vegetative reproduction. New leaves appear in spring, and the plant grows by increasing the density of shoots derived from the continuous branching rhizome (Auby et Labourg, 1996; Ribaudo et al., 2016). Zostera noltei beds have an important role in biological equilibrium (Mccloskey and Unsworth, 2015; Bostrom et al, 2014) as they increase the spatial heterogeneity of habitat, leaves allow wildlife to take shelter against predators and they help to oxygenate the rhizosphere. The presence of seagrass promotes diversity and 
abundance of aquatic fauna. Dwarf eelgrass, is a stabilizer, reducing hydrodynamic constraints on the sediment, reducing the rate of resuspension of fine particles and thus promoting water transparency and primary production (Ganthy et al., 2015).

Since 2005, a significant decrease in Z. noltei biomass has been observed leading to the disappearance of this species in the eastern areas of the Bay (Plus et al., 2010 ; Auby et al. 2011). Indeed, seagrass bed coverage decreased of 33\% between 2005 and 2012 and this decline is still in progress to date. This decline is observed both in subtidal and intertidal areas. Many causes such as birds eating have been hypothesized to be involved in this decrease (Auby et al., 2011). However, the impact of seasonal temperature and of pollutants have not been explored to date.

In this context, the main objective of this study was to determine the impact of pollutants (pesticide cocktail and $\mathrm{Cu}$ ) and of temperature on physiological and cellular functions of $Z$. noltei. Indeed, these chemical compounds have an effect on the development of weeds and can therefore negatively impact other plants physiology. For this purpose, Z. noltei collected in a pollution-free site of Arcachon Bay were exposed in the laboratory to the pesticide cocktail and $\mathrm{Cu}$, separately or simultaneously, for two weeks at temperatures $\left(10{ }^{\circ} \mathrm{C}, 20^{\circ} \mathrm{C}\right.$, $\left.28{ }^{\circ} \mathrm{C}\right)$ representative of different seasons. To determine the physiological and molecular effects of exposure, morphometric modifications, bioaccumulation and genetic impacts were studied including leaf growth, $\mathrm{Cu}$ bioaccumulation and expression levels of target genes involved in mitochondrial metabolism, photosystems I and II and oxidative stress responses. All these cellular functions were chosen to investigate the molecular impacts on mitochondria and chloroplasts which were previously described as putative primary target of pesticides and $\mathrm{Cu}$ in cells (Sako et al, 2016; Gomes et al, 2017). Results obtained during this experimental approach were completed by a field survey, from March to July 2014, of the health status of Arcahon Bay eelgrass. Here, gene expression levels were compared in individuals harvested at four sites in Arcachon bay, two sites where Z. noltei is in decline and two apparently pristine sites. The aim of this field survey was to determine if impacts observed during the experimental study could be recovered in the environment.

\section{II - Materials and methods}

\subsection{Experimental design}

A pre-experiment established the following optimal conditions i) three temperatures based on seasonal variations observed in the eastern part of the bay where decline was 
observed: $10^{\circ} \mathrm{C}$ mimicking winter, $20^{\circ} \mathrm{C}$, mimicking spring and optimum growth and $28^{\circ}$ $\mathrm{C}$, mimicking summer; ii) the most appropriate marking protocol to determine leaf growth ; iii) no nutrient supplementation in seawater. Prior to the pre-experiment, an auto analyzer stream (AA3 Seal Analytical) indicated a need for phosphate supplementation to obtain concentrations necessary for optimal Z. noltei growth (Plus, 2001). However, no significant differences in Z. noltei growth were observed between supplemented and unsupplemented water and finally no nutrient supplementation was used.

The experiment was carried in experimental units (EUs), $20 \mathrm{~cm}$ height x $30 \mathrm{~cm}$ x 25 $\mathrm{cm}$, filled with 6 liters of seawater from the Arguin sandbar (Figure 1). Dwarf eelgrass sampling was carried, in May, out at low tide in Arcachon Bay near the Arguin sandbar, a pollution-free site. Clumps of eelgrass rooted in their substrate were collected in intertidal areas and installed in coolers containing a little water from the sampling zone to maintain the field temperature $\left(19^{\circ} \mathrm{C}\right)$. Before introduction into the EUs, the sediment clods were washed in the laboratory under a low water current, over a sieve (mesh of $2.50 \mathrm{~mm}$ ) to separate and retain only the eelgrass shoots, with their rhizomes (underground stems) and roots, but without sediment. This process is recognized as not being harmful for Z. noltei (Plus, 2001), and it overcomes the problems of potential contaminants complexed with the sediment compartment. Once isolated, nine Z. noltei plants were tied individually with a nylon string containing glass beads at the end and immersed in each EU. Plants were randomly positioned to account for variations in light intensity (range 35-50 $\mu \mathrm{mol}$ of photons. $\mathrm{m}^{2} \cdot \mathrm{s}^{-1}$ ) under a photoperiod of $16 \mathrm{~h} / 8 \mathrm{~h}$. This light intensity was near that encountered in the environment by this species in the Arcachon Bay.

Dwarf eelgrass were exposed to final temperatures of $10{ }^{\circ} \mathrm{C}, 20{ }^{\circ} \mathrm{C}$ and $28{ }^{\circ} \mathrm{C}$ after an acclimation period of 8 days during which the temperature was increased $2^{\circ} \mathrm{C}$ per day to reach final values. For this purpose, EUs were incubated in large water baths to ensure a constant and a homogenous temperature. Temperature in each EU was follow individually every days. Five conditions were studied at each temperature: i) a "control", ii) a "solvent" to ensure the safety of the solvent used in the pesticide cocktail, iii) a "cocktail of pesticides", iv) a "copper" only and v) a mixture "cocktail of pesticides + copper". For each temperature and each condition, there were three replicates, each containing nine eelgrass plants: five were used to study eelgrass growth and $\mathrm{Cu}$ bioaccumulation, and four for genetic analyses. 


\subsection{Contamination procedure}

For all conditions, contamination was through the water column at a constant contamination pressure for 14 days. Experimental contaminant concentrations were tenfold higher than those analyzed in the environment.

\subsubsection{Copper contamination}

The contamination solution $\left(0.1 \mathrm{mg} \mathrm{CuCl}_{2} \cdot \mathrm{L}^{-1}\right)$ was obtained by dilution of a stock solution of $1 \mathrm{mg} \mathrm{CuCl}_{2} \cdot \mathrm{L}^{-1}$. At T0, $0.6 \mathrm{~mL}$ of this solution was added to each UE "Copper" to obtain the experimental contamination of $10 \mu \mathrm{g} \mathrm{CuCl} 2 . \mathrm{L}^{-1}$. Every day, $\mathrm{Cu}$ concentration was analyzed by spectrometry plasma torch 720 Agilent ICP-OES and concentrations adjusted by addition of aliquots of the contamination solution to maintain the experimental concentration.

\subsubsection{Pesticide cocktail contamination}

This pesticide solution contained 15 compounds typically found in the bay, mainly from agriculture (herbicides, insecticides) and boats coating (antifouling, herbicides and biocides $)$, diluted in acetonitrile $(0.1 \% \mathrm{v} / \mathrm{v})$. The relative amount of each reagent was adjusted to be identical to that observed in Arcachon bay near the Leyre river outlet. Compounds used and their relative concentrations in the pesticide cocktail are reported in Table 1. Decreases in irgarol, S-metolachlor and acetochlor have been reported in similar experimental conditions (LPTC personal communication), thus additional quantities of these compounds were added every two days (T2, T4, T6, T8, T10, T12) with a solution of intermediate contamination (Table I) to compensate this decrease and to ensure a constant contamination pressure. For the solvent control, pure acetonitrile was introduced at T0 to a final concentration of $0.1 \% \mathrm{v} / \mathrm{v}$. Water samples were taken every two days, stored at $-20{ }^{\circ} \mathrm{C}$ and analyzed via solid phase extraction (SPE) with LC / MS / MS (Liquid Chromatography / Tandem Mass Spectrometry) in MRM mode (Multiple Reaction Monitoring) to determine pesticide concentrations throughout the duration of the experiment. Test concentrations were compared to desired nominal concentrations to refine the diagnostic impact.

\subsection{Field experiment}

Dwarf eelgrass plants were collected in March, May and July at two sites in the internal part of the bay were no decline of Z. noltei was observed (Africa and Hautebelle) and two sites in the eastern part of the bay (Estey tort and Matoucail) clearly impacted by seagrass 
decline (Figure 1). At each harvest, plant leaves and roots were separated and conserved at minus $80{ }^{\circ} \mathrm{C}$ in $500 \mu \mathrm{L}$ of RNA later (Qiagen) for future transcriptomic analysis.

\subsection{Study endpoints}

\subsubsection{Growth}

Determined as most appropriate prior to the experiment (see Section 2.1), the method described by Zieman (1974), modified by Vermaat et al. (1987) and adapted by Ribaudo et al.(2016) was used. Here, using a needle, all the leaves of the shoots were pierced at the top of the leaf sheath at the beginning of the experiment.

At the end of the 14-day exposure period, all leaves of each shoot were enumerated and measured. For each leaf, the total length above the sheath $\mathrm{Li}(\mathrm{mm})$, the length of new plant material produced (between the top of the sheath and the hole on the leaf), called length increase ci $(\mathrm{mm})$ and the width li $(\mathrm{mm})$ were measured. New leaves, unmarked because located in the sheath at the beginning of the experiment, may occur. Their growth is then equal to the total surface of the leave above the sheath.

Three replicates of ten leaves of different ages from supplementary shoots were measured and weighed (Dry weight - after two days at $60{ }^{\circ} \mathrm{C}$ ), to get the ratio between mass and leaf area $\mathrm{R}\left(\mu \mathrm{g} \mathrm{dw} \cdot \mathrm{mm}^{-2}\right)$.

Plant growth was described by the following exponential formula (Vermaat et al. 1987):

$$
\mathrm{Bf}=\mathrm{Bo} \times \mathrm{e}^{\mu \mathrm{t}}
$$

where $\mathrm{Bf}$, the final biomass $(\mu \mathrm{g} \mathrm{dw})$; Bo, the initial biomass $(\mu \mathrm{g} \mathrm{dw}) ; \mu$, the relative growth rate $\left(d^{-1}\right)$ and $t$, the time period considered $(d)$. The relative growth rate $\mu$ was based on the growth of all the leaves; It was obtained from the equation:

$$
\mu=\frac{\ln (B O+C)-\ln B o}{\tau}
$$

The calculation of the initial biomass $\mathrm{Bo}$ is: $\mathrm{Bo}=\mathrm{Bf}-\mathrm{C}$, with:

$$
B f=R \times \sum_{i=1}^{n}\left(L_{i} \times l_{i}\right) \quad C=R \times \sum_{i=1}^{n}\left(c_{i} \times l_{i}\right)
$$

where R (ug dw.mm ${ }^{-2}$ ) expresses the ratio between mass and leaf area, n (leaves.shoot-1) expresses the total number of leaves on the shoot, i representing a leaf of the shoot. 


\subsubsection{Bioaccumulation of copper}

Copper concentration was determined at T0 and T14 in the eelgrass leaves to evidence the bioaccumulation of this compound. After drying for $48 \mathrm{~h}$ in a $45{ }^{\circ} \mathrm{C}$-oven, the samples were heated for $3 \mathrm{~h}$ at $100{ }^{\circ} \mathrm{C}$ in the presence of $63 \%$ nitric acid $(2 \mathrm{~mL})$. This digested organic matter releases bioaccumulated metals in ionic form which allows determination of the total amount of metal. After cooling, samples were diluted by adding $8 \mathrm{~mL}$ of ultra-pure water (MilliQ) and stored in a cold room at $4{ }^{\circ} \mathrm{C}$ until analysis by spectrometry ICP-plasma torch Agilent 720 OES accompanied by two sample controls (acid alone) and 4 certified samples. For pesticides, the amount bioaccumulated in dwarf eelgrass could not be assayed.

\subsubsection{Genetic study}

\subsubsection{Studied genes}

A transcriptomic study was conducted to evidence putative impacts of $\mathrm{Cu}$ and pesticide cocktail on seagrass. In this way, the nine genes studied were cloned and sequenced beforehand for the species Z. noltei and were known to be involved in metabolic pathways putatively impacted by pollutants (Moisset et al, 2015). The $\beta$ actin gene (act), involved in the formation of the cellular cytoskeleton, was chosen as the reference gene and, under the conditions here, this gene exhibited a stable expression profile. Three of the studied genes were involved in the oxidative stress response, i.e. mitochondrial superoxide dismutase $(\operatorname{sod} M n)$, catalase (cat) and glutathione peroxidase ( $g p x 1)$; three in mitochondrial metabolism, subunit 1 of cytochrome c oxidase ( $\operatorname{cox} 1)$, sub-unit 5 of NADH dehydrogenase (nad5) and $12 \mathrm{~S}$ ribosomal RNA; and two in the functioning of photosystems, the photosystem I (psaA) and photosystem II $(d l)$. Accession numbers are indicated in Table 2.

\subsubsection{Extraction of total RNA}

Two shoots of eelgrass for each condition and each replicate were taken at $\mathrm{T}=7$ and $\mathrm{T}=14$ days. In the field experiment, two shoots were harvested at the 4 sites. For all, leaves were isolated, introduced into microtubes containing $600 \mu \mathrm{L}$ of RNA Later and stored at $-20{ }^{\circ} \mathrm{C}$ until total RNA extraction using the "Absolutely RNA Miniprep Kit" (Agilent) from 20 to 40 mg of plant tissue following the manufacturer's recommendations.

\subsubsection{Retro-transcription}

RT was performed using the kit "Stratascript first strand synthesis system" (Agilent) from 14 $\mu \mathrm{L}$ of total RNA (1 to $3 \mu \mathrm{g}$ ). $1 \mu \mathrm{L}$ of an oligo dT solution $[1 \mu \mathrm{M}], 1 \mu \mathrm{L}$ of a hexanucleotide solution $[1 \mu \mathrm{M}], 0.8 \mu \mathrm{L}$ of a dNTP solution [10 mM], and $2 \mu \mathrm{L}$ of buffer activity $10 \mathrm{X}$ were added to RNAs. The sample was placed in a thermocycler (Eppendorf Mastercycler) for $5 \mathrm{~min}$ 
at $65^{\circ} \mathrm{C}$ to linearize RNAs, and allow primers (hexaprimers and oligodT) to fix. Then $1 \mu \mathrm{L}$ of reverse transcriptase [1U. $\left.\mu \mathrm{L}^{-1}\right]$ and $0.5 \mu \mathrm{L}$ of RNase block [0.5U] were added. The samples were placed in a thermocycler for 1 hour at $42{ }^{\circ} \mathrm{C}$. The cDNAs were stored at $-20{ }^{\circ} \mathrm{C}$ until their use in real-time quantitative PCR reactions.

\subsubsection{PCR-quantitative real-time}

Differential expression of the studied genes was performed by MX3000P (Stratagene) using the "Brilliant III Ultra Fast SYBR Green QPCR Master Mix" (Agilent). Specific Primer-pairs were determined using the Lightcycler probe design software (Table 2). Each PCR reaction was performed in 96-well plates and included $17 \mu \mathrm{L}$ of reaction mix $(10 \mu \mathrm{L}$ of $\mathrm{Tp} 2 \mathrm{X}$ (Syber green, Taq polymerase, dNTPs, $\left.\mathrm{MgCl}_{2}\right)$, and $\left.7 \mu \mathrm{L} \mathrm{H}_{2} 0\right), 2 \mu \mathrm{L}$ of specific primer-pairs $(2 \mu \mathrm{M}$ each) and $1 \mu \mathrm{L}$ of the corresponding cDNA sample. The program began with enzyme activation $\left(95{ }^{\circ} \mathrm{C}\right.$ for $\left.10 \mathrm{~min}\right)$ followed by 40 cycles of PCR: $95{ }^{\circ} \mathrm{C} 30 \mathrm{~s}, 55^{\circ} \mathrm{C} 30 \mathrm{~s}, 72{ }^{\circ} \mathrm{C} 30 \mathrm{~s}$. The quality of the amplification products was checked by analysis of thermal melting curves, conducted by gradually increasing the temperature from 60 to $95{ }^{\circ} \mathrm{C}$. The level of expression of each gene was determined relative to the reference gene ( $\beta$-actin) using the $2 \Delta \mathrm{Ct}$ method described by Livak and Schmittgen (2001).

\subsection{Statistical Analysis}

Significance of differences between each experimental condition was determined using the $\mathrm{R}$ software (http://cran.r-project.org/). The same statistical software was used for transcriptomic results obtained during field survey. The normality of data distribution was checked using the Shapiro-Wilk test. Variance homogeneity was evaluated using the Bartlett test. In case of homogenous variance and data following a normal distribution, ANOVA analysis was performed, followed by the Tukey post-hoc test. Otherwise, data was analysed using the Kruskal-Wallis a non-parametric test. For all tests, $\mathrm{p}<0.05$ was considered significant. For experimental results, Principal Component Analysis (PCA) and Spearman's Rank Correlation Analysis (SRCA) were used to provide a synthetic view of the gene expression profiles associated to the different treatments. Computations were performed using STATISTICA version 6.1 software (StatSoft, USA) and XLSTAT (Addinsoft version 2012.6.08). 


\section{III - Results}

\subsection{Copper concentration in experimental units and copper bioaccumulation in Z.noltei}

Water analysis showed 5-6 days were required to exactly achieve the desired concentration of $10 \mu \mathrm{g} \mathrm{Cu} . \mathrm{L}^{-1}$ in EUs (data not show), thus the average $\mathrm{Cu}$ exposure was $9.2 \mu \mathrm{g} . \mathrm{L}^{-1}$ at $10{ }^{\circ} \mathrm{C}$ and $8.7 \mu \mathrm{g} . \mathrm{L}^{-1}$ at 20 and $28{ }^{\circ} \mathrm{C}$ throughout the experiment. In EUs contaminated with pesticide cocktail and $\mathrm{Cu}$, average exposure was $8.5 \mu \mathrm{g} . \mathrm{L}^{-1}$ at 10 and $20{ }^{\circ} \mathrm{C}$ and $9 \mu \mathrm{g} . \mathrm{L}^{-1}$ at 28 ${ }^{\circ} \mathrm{C}$.

In control conditions at the different temperatures $\left(10{ }^{\circ} \mathrm{C}, 20{ }^{\circ} \mathrm{C}\right.$ and $\left.28{ }^{\circ} \mathrm{C}\right)$, no significant bioaccumulation was evidenced were T0 and T14 were compared (Figure 2). Indeed, $\mathrm{Cu}$ concentration in leaves did not appear significantly different between $\mathrm{T} 0$ and $\mathrm{T} 14$ for controls Z. noltei at each temperature. After 14 days, Z. noltei exposed to mixture "copper + cocktail" bioaccumulated significantly less copper at $28^{\circ} \mathrm{C}: 6$ times less and 4 times less than $10{ }^{\circ} \mathrm{C}$ or $20{ }^{\circ} \mathrm{C}$, respectively. At $28{ }^{\circ} \mathrm{C}$, Z. noltei contaminated with "copper +cocktail" accumulated 5 fold less $\mathrm{Cu}$ than plants contaminated with $\mathrm{Cu}$ alone. For Z. noltei contaminated with copper alone, no significant difference of bioaccumulation was observed between the three exposure temperatures.

\subsection{Z. noltei leaf growth}

There was no mortality at any temperature in the control condition. In contaminated conditions, mortality increased as the exposure temperature increased. Indeed, while few mortality was observed at $10{ }^{\circ} \mathrm{C}$ and $20{ }^{\circ} \mathrm{C}, 20 \%$ of Z. noltei plants in contaminatedconditions were dead at $28{ }^{\circ} \mathrm{C}$.

A significant effect of temperature on the growth rate of Z. noltei (Kruskal-Wallis, p-value $=$ 0.00089, $\mathrm{df}=29$ ) was observed in which all the individuals at $28{ }^{\circ} \mathrm{C}$ exhibited a lower growth rate than individuals at 10 and $20{ }^{\circ} \mathrm{C}$. In contrast, no significant differences were observed between 10 and $20^{\circ} \mathrm{C}$.

At each temperature, there were significant differences in growth rate based on treatment (Figure 3). At $10{ }^{\circ} \mathrm{C}$, a significant effect on growth rates between the control and eelgrasses exposed to pesticides cocktail or mixture " $\mathrm{Cu}+$ cocktail» was evidenced while there was no effect of copper alone. For the three conditions of contamination, Z. noltei exposed to $\mathrm{Cu}$ showed a significantly different growth than Z. noltei exposed to cocktail, but neither $\mathrm{Cu}$ nor 
pesticide cocktail were different from the " $\mathrm{Cu}+$ cocktail" condition. At $20^{\circ} \mathrm{C}$, neither $\mathrm{Cu}$ nor cocktail had a significant effect on growth alone, yet together they decreased growth rate. At $28{ }^{\circ} \mathrm{C}$, there was a dramatic decrease in growth rate for all the exposure conditions. The lowest values were reported for plants exposed to contaminants with values always under 0.01 days $^{-1}$. There was a significant difference between dwarf eelgrass exposed to contaminants alone and those exposed to mixture « $\mathrm{Cu}+$ cocktail". Controls and solvent controls show no significant difference in growth between temperatures.

\subsection{Genetic study}

\subsubsection{Gene expression in controls exposed to different temperatures}

Analysis of gene expression showed a basal expression for each temperature at each sampling time. Basal expression was significantly different between $10{ }^{\circ} \mathrm{C}, 20^{\circ} \mathrm{C}$ and $28^{\circ} \mathrm{C}$ at $\mathrm{T} 7$ and T14 (Table III). At T7, compared to the basal expression observed at $20^{\circ} \mathrm{C}$, the expression levels at $10{ }^{\circ} \mathrm{C}$ of $12 \mathrm{~S}$, sodMn, gpxl, psaA were increased, while cat and $d l$ were significantly reduced. At the same sampling time, coxl gene, nad5, 12S, $d 1$ showed lower basal expression values at $28{ }^{\circ} \mathrm{C}$ compared to $20{ }^{\circ} \mathrm{C}$, but sodMn and gpxl appeared to be higher. At T14, significant decreases in expression of $\operatorname{sodMn}, d l, \operatorname{coxl}, 12 \mathrm{~S}$ were seen at $10{ }^{\circ} \mathrm{C}$ and $28{ }^{\circ} \mathrm{C}$ compared to $20^{\circ} \mathrm{C}$.

\subsubsection{Gene expression in experimentally contaminated eelgrass}

In copper-contaminated units at $\mathrm{T} 7$ there were no significant effects at $10{ }^{\circ} \mathrm{C}$. At $20^{\circ} \mathrm{C}$, there were decreases in the expression of genes involved in mitochondrial metabolism, the oxidative stress response (cat) and the genes of photosystem II $(d l)$ while the glutathione peroxidase gene was overexpressed. At $28{ }^{\circ} \mathrm{C}$, there was induction of genes involved in mitochondrial activity $(\operatorname{cox} 1,12 S)$ and photosynthetic activity $(d 1)$ and a decrease in genes responding to oxidative stress ( $\operatorname{sodMn}$, gpxl), with overall differential expressions greater than at 10 and $20{ }^{\circ} \mathrm{C}$. After 14 days of contamination with copper at $10{ }^{\circ} \mathrm{C}$, there was a decrease in the expression of genes $p s a A$, cat, sodMn and an increase in the expression of genes coxl, gpx and $d 1$. At $20{ }^{\circ} \mathrm{C}$, the repression of mitochondrial activity genes continued and two genes of photosystems I and II were repressed. The strongest effects were at $28{ }^{\circ} \mathrm{C}$, with a significant induction of genes of mitochondrial activity (146 and 45 fold increase for coxI and 12S, respectively), genes involved in the oxidative stress response (51 fold induction of sodMn) and photosystem genes (152 fold for $p s a A$ and 146 fold for $d 1$ ). 
There were few modifications in gene expression patterns at $\mathrm{T} 7$ at $10{ }^{\circ} \mathrm{C}$ in the cocktail of pesticide contamination condition, only cat, $12 \mathrm{~S}$ and $p s a A$ were slightly overexpressed. The same was true at $20{ }^{\circ} \mathrm{C}$, where only gpxl and psaA were increased. At $28{ }^{\circ} \mathrm{C}$, however, expression of the mitochondrial genes ( $\operatorname{coxl}$ and 12S) and photosystem II increased between 3 and 84 times. Expression of cat and sodMn was inhibited, while a third gene involved in defense against ROS, glutathione peroxidase, was induced. At T14, expression of almost all genes studied was increased at all temperatures, with the highest increases usually at $28{ }^{\circ} \mathrm{C}$.

When both contaminants were applied together at 7 days and at $10{ }^{\circ} \mathrm{C}$, inhibition of mitochondrial metabolism (coxl and nad5), photosynthetic activity (dl) and sodMn genes was observed, while cat gene expression was increased. At $20{ }^{\circ} \mathrm{C}$, there was induction of genes $12 \mathrm{~S}$, psaA and gpxl. At $28{ }^{\circ} \mathrm{C}$, expression of mitochondrial metabolism genes (coxl, nad5, 12S) and photosystem II increased, but there was a significant inhibition of oxidative stress response genes (sodMn, cat, gpxl). By 14 days of contamination, there was a gradual increase in the expression of almost all genes studied, again aligned with temperature increases. Thus, at $10{ }^{\circ} \mathrm{C}$, only nad5, $12 \mathrm{~S}$, cat and $d l$ were induced. At $20^{\circ} \mathrm{C}$, only cat and $d l$ were similar to control. At $28^{\circ} \mathrm{C}, d l$ and $g p x l$ were identical to control while all other genes were overexpressed between 17 and 126 fold.

\subsection{Principal Component Analysis}

Principal Component Analysis (PCA) and Spearman's Rank Correlation Analysis (SRCA) were used to provide a synthetic view of the gene expression profiles associated to the different treatments (Figure 4). Axis 1 is mainly defined by exposure; from left to right we have $\mathrm{C}, \mathrm{Cu}, \mathrm{Co}$ and $\mathrm{CuCo}$. Genes strongly associated with axis 1 are $12 \mathrm{~s}, n d 5$ and psaA. They appeared to be more influenced by exposure to $\mathrm{Co}$ and especially $\mathrm{CuCo}$ than by temperature. The exposure to these contaminants must have an impact on growth and then these three genes are significantly negatively correlated to growth.

Axis 2 was much related to temperature. It can be seen that the temperature is negatively correlated with growth, $d l$ and especially gpxl. These three parameters seem to be more influenced by temperature than by exposure, this is especially true for gpxl.

\subsection{Field analysis}

The same genes as above were evaluated in plants harvested in March, May and July in 4 sites of Arcachon Bay. All expression levels were normalized according to those in Afrique based 
on location of this site near the oceanic part of the Bay and the lack of eelgrasses decline in it. Results showed that Hautebelle had nearly the same expression profiles as Afrique (Table V), with only sodMn and cat repressed in May and overexpressed in July, and a 2 fold increase for photosynthetic genes in May. On the contrary, Estey tort and Matoucail showed reduced expression of genes involved in mitochondrial metabolism and photosynthesis in March, while in May and July most of the investigated genes were overexpressed, with the highest values observed in May when there was 35 and 145 fold increased expression in Estey tort for $d l$ and $p s a A$, respectively.

\section{IV.Discussion}

In this study, an ex-situ approach has been conducted to be able to control factors such as temperature and concentration of contaminants, using concentrations ten times higher than those observed in the eelgrass environment. Three different seasonal temperature observed in the eastern part of the bay where Z. noltei decline has been observed were used $\left(10^{\circ} \mathrm{C}, 20{ }^{\circ} \mathrm{C}\right.$ and $28{ }^{\circ} \mathrm{C}$ ). The exposure time of 14 days is short compared to the almost constant contamination Z. noltei encounter in Arcachon bay, but this first step allowed discrimination of the effects of contaminants on various endpoints (growth, bioaccumulation, genetic expression).

The highest growth rate was for plants in control conditions at 10 and $20{ }^{\circ} \mathrm{C}$, with no significant difference between these temperatures, although the genetic study showed higher basal expression at $20{ }^{\circ} \mathrm{C}$. At a temperature of $28{ }^{\circ} \mathrm{C}$, the significantly lower growth rate for control eelgrass after 14 days could be related to much lower expression levels of all the studied genes. Therefore, results show that Z. noltei growth is highly correlated with water temperature and appears optimal at $20^{\circ} \mathrm{C}$ whereas high temperatures slow it down. This is correlated with water temperatures at the beginning of eelgrasses growth (early spring: 18-20 ${ }^{\circ} \mathrm{C}$, Ribaudo et al, 2016). This optimal temperature of $20{ }^{\circ} \mathrm{C}$ is consistent with what is reported for other Zosteraceae, with optimum evidenced to range between 15 and $23{ }^{\circ} \mathrm{C}$ in temperate areas (Lee et al, 2007). This temperature effect on Z. noltei growth is mainly visible in situ during summer season when the hot temperatures affect eelgrasses during low tides periods. Due to east-west gradients, distance to the ocean and depth, eastern areas of the bay are exposed to temperature fluctuations of greater amplitude than areas further west. However, periods of high temperatures appear to have increased during the last decade, 
including heat waves in the summers of 2003 and 2006 (Auby et al. 2011). In coastal areas, the main consequences now proven were, among other things, an increase in global temperatures, oscillating, according scenarios, between $1.5{ }^{\circ} \mathrm{C}$ and $6{ }^{\circ} \mathrm{C}$ for the end of this century (GIEC, 2001). However, present overview showed that significant regression of seagrasses in the most eastern area of the bay could partly be induced by increased temperature which, as shown here, is probably a threat to their growth. This is in agreement with a recent report on the regression of sea grass (Auby et al. 2011) which mentioned a possible match between the seagrass decline and the frequency of high temperatures, especially in the southern bay and on its eastern edge, making the role of high temperatures (air and water) a plausible explanation for the seagrass initial regression within the bay. In addition to the effects of increased temperature, this study showed that the effects of the various contaminants in Arcachon bay should be taken into account.

Regarding the effects of contaminants, there is a lack of toxicological data on the effects of herbicide cocktails and / or the effects of metabolites. Indeed, such studies applied to Z. noltei are still scarce (Lewis and Devereux, 2009; Diepens et al, 2017). Moreover, these studies do not support any conclusions on the effect of chemical compounds on dwarf eelgrasses populations. In this work, growth rates were significantly different between 10 and $28{ }^{\circ} \mathrm{C}$ and between 20 and $28{ }^{\circ} \mathrm{C}$. However, there was no difference between 10 and $20{ }^{\circ} \mathrm{C}$ for each contaminant used alone and mixed, suggesting an exacerbation of the effect of contaminants at high temperatures.

$\mathrm{Cu}$ is an essential metallic element for living organisms, but it becomes toxic at elevated concentration, depending on the organism (Flemming and Trevors, 1989). Seagrasses can accumulate trace metals such as $\mathrm{Cu}$ from the marine environment (Prange and Dennison, 2000). Indeed, in this study, Prange and Dennison evidenced that the $\mathrm{Cu}$ content of leaves from 5 seagrass species (Halophila ovalis, H. spinulosa, Halodule uninervis, Zostera capricorni, and Cymodocea serrulata), harvested in contaminated areas in the Queensland, could reached from 1 to $20 \mu \mathrm{g} \cdot \mathrm{g}^{-1}$ according to $\mathrm{Cu}$ contamination pressure. Results obtained in this study revealed that $Z$. noltei contaminated with $\mathrm{Cu}$ accumulated on average 28 times more $\mathrm{Cu}$ than eelgrass in control conditions, whatever the temperature. Therefore, there was no effect of temperature on the potential $\mathrm{Cu}$ bioaccumulation. In a recent report, Govers et al (2014) evidenced that concentration of $\mathrm{Cu}$ in seagrass leaves could range from 1 to nearly 90 $\mu \mathrm{g} \cdot \mathrm{g}^{-1}$ according to the species. 
At $10{ }^{\circ} \mathrm{C}, \mathrm{Cu}$ had no effect on dwarf eelgrass growth but a decrease of differential gene expression was noticeable after 14 days. Presumably time would be required for contaminants to have an effect. Metal toxicity was closely related to factors controlling plant tolerance, including chemical interactions such as chelation (Prange, 2000) performed by phytochelatins, metal sequestering proteins, responsible for tolerance to metal ions which act in the early days of contamination Rauser (1995). This would explain the lack of clear $\mathrm{Cu}$ effect at $10{ }^{\circ} \mathrm{C}$ during the first days of contamination.

At $20{ }^{\circ} \mathrm{C}$, no significant inhibition of growth occurred. However at 7 days of contamination, $\mathrm{Cu}$ inhibited expression of all genes studied, except gpxl which was induced. This gene is ubiquitously expressed in eukaryotic cells and plays a central role in protecting cells against oxidative damage (Briat and Lebrun, 1998). This may explain its induction. Indeed, $\mathrm{Cu}$ induces the production of reactive oxygen species (ROS) and free radicals because it stimulates reactions such as the Haber-Weiss and Fenton, which produce these molecules (Hall, 2002). The bioaccumulation data revealed that $\mathrm{Cu}$ concentrations, in our experiment, were similar among the three temperatures after 14 days of contamination, indicating that phytochelatins were no longer trapping $\mathrm{Cu}$, all genes being inhibited after 14 days.

At $28{ }^{\circ} \mathrm{C}, \mathrm{Cu}$ caused a significant decrease in the growth rate compared to $10{ }^{\circ} \mathrm{C}$ and $20{ }^{\circ} \mathrm{C}$. From 7 days of contamination, effects on gene expression were also important at this temperature. After 14 days-exposure, a significant impairment of mitochondrial metabolism appeared. Indeed, the number of mitochondria (12S gene) as well as the expression levels of coxl (complex IV of the mitochondrial respiratory chain, located on the inner membrane of mitochondria) and nad5 (complex I) increased, probably to maintain a sufficient pool of ATP and viability of cells. This result was in agreement with recent report of Sako et al. (2016) where $\mathrm{Cu}$ was demonstrated to highly accumulated in mitochondria of the plant Hyoscyamus albus. Moreover, they evidenced that high $\mathrm{Cu}$ levels enhanced respiration activity and comparative proteomic analysis revealed that proteins involved in carbohydrate metabolism and ATP synthesis increased in abundance.. Therefore, at $28{ }^{\circ} \mathrm{C}, Z$. noltei try to counteract $\mathrm{Cu}$ impacts. Genes involved in the fight against reactive oxygen species (ROS) were strongly induced and, as $\mathrm{Cu}$ has been shown to induce ROS production (Hall, 2002), that could explain the significant gene induction observed. However, this increase in ROS could also be due to the increased number of mitochondria. Indeed, the electron chain found in the mitochondrial membrane has been shown to be the major site of ROS production, particularly at complex I 
(Turrens, 1997). Exacerbating the effect of $\mathrm{Cu}$, rising temperatures have a strong impact, suggesting that, at these temperatures, the detoxification function of phytochelatin could not be efficient enough to defend Z. noltei. In future experiments, phytochelatin amounts could serve as a marker of exposure to trace metals as they would reflect the response of the plant to these toxic substances.

After 7 days of contamination and at the three temperatures, no $\mathrm{Cu}$ effect on photosystem I was observed. On the contrary, there was an impact on photosystem II at $28{ }^{\circ} \mathrm{C}$. This result is consistent with previous research showing that $\mathrm{Cu}$ could affect the pigment-protein complex of photosystem II when present in excess (Cook et al., 1997; Droppa et al., 1984; Mohanty, 1988; Patsikka et al. 2002). It seems that photosystem II is a prime target of $\mathrm{Cu}$ in the early days of contamination, in contrast to photosystem I. After 14 days, the two photosystems were affected at $28{ }^{\circ} \mathrm{C}$, indicating that the dwarf eelgrass could no longer prevent disturbance of photosynthesis processes.

Therefore, $\mathrm{Cu}$ action was stronger with temperature increase and exposure time. In this way, Zevenhuizen et al. (1979) have observed that $\mathrm{Cu}$ damage to bacteria is based on the exposure time. In addition, it has been shown that the speciation of an element governs its toxicological properties, particularly for metals. Forms may change depending on the physicochemical conditions of the environment such as temperature (Flemming and Trevors, 1989), so the rise in temperature could lead to $\mathrm{Cu}$ speciation changes making it more absorbable by $\mathrm{Z}$. noltei. Since bioaccumulation remained the same regardless of temperature, this hypothesis is refuted in our study. The author also stated that $\mathrm{pH}$ and redox potential were the main factors affecting $\mathrm{Cu}$ toxicity. Therefore, in future studies, these two parameters should be followed to better understand $\mathrm{Cu}$ action at elevated temperatures.

Contamination with the pesticide cocktail led to an increase in mitochondria (12S gene), and an overexpression of $\operatorname{cox} 1$ and $\operatorname{nad} 5$ genes at $28^{\circ} \mathrm{C}$. This would allow maintaining a sufficient pool ATP and cells viability, offsetting the deleterious effect of the contaminant (Sako et al. 2016). Moreover, $20 \%$ mortality was observed at the same temperature after 14 days exposure and correlates with the reduced growth induced by the pesticide. Therefore, summer temperatures and the presence of a cocktail of pesticides would make organisms suffer. Moreover, overexpression of genes involved in photosynthesis, after pesticide exposure, agreeing with a recent report from Diepens et al. (2017). Indeed, those authors used an Atrazine, Diuron, irgarol and S-metolachlore mixture at 1, 10, 100 and $1000 \mu \mathrm{g} . \mathrm{L}^{-1}$ on $Z$. 
noltei. They showed a clear increase in photosynthetic pigment for concentrations above $10 \mu \mathrm{g} . \mathrm{L}^{-1}$ after $6 \mathrm{~h}$ exposure. Taken together, these results could indicate that mitochondria and photosystems constitute the major target of pesticides and that the overexpression of corresponding genes is to maintain the energetic potential of seagrasses, probably to fight against adverse effects of these compounds.

At $20{ }^{\circ} \mathrm{C}$ the mixture did not cause growth inhibition nor cause mortality, although effects on metabolism were noticeable. This may be because it was the optimum temperature for $Z$. noltei growth, thus offsetting the negative effect of the cocktail. Therefore, the impact of pesticides was higher when temperature were higher and exposure time longer. Previous studies have already shown that high air temperatures amplify the toxic effects of chemical molecules (Gordon, 2003). It is reasonable to assume that this may also be applicable in the aquatic environment, as reported recently by Gandar et al (2016). In addition, it appears that the action of the cocktail was stronger than $\mathrm{Cu}$ action at the three temperatures, both after 7 and 14 days, when there was an induction of all three gene functions studied. It has been shown that diuron, one of the pesticides in the cocktail, results in greater inhibition of growth than $\mathrm{Cu}$ on the duckweed Lemna minor at concentrations of 10, 20 and $30 \mu$ g.L. $\mathrm{L}^{-1}$ (Teisseire et al. , 1999), and this may explain the result here.

However, in the natural environment, all contaminants are found in the water simultaneously. In this study, it was demonstrated that the combination of $\mathrm{Cu}$ and pesticide cocktail led to significant inhibition of $Z$. noltei growth at 10,20 and $28{ }^{\circ} \mathrm{C}$, while none of the contaminants used alone had an effect at $20^{\circ} \mathrm{C}$. In addition, at $28^{\circ} \mathrm{C}$ the $\mathrm{Cu}+$ cocktail had a higher effect than $\mathrm{Cu}$ or cocktail alone, which was even larger at higher temperature. This was also found in the genetic analyses.

Differential gene expression revealed, from day 7 and at 20 and $28{ }^{\circ} \mathrm{C}$, an increase in the expression of all genes studied. This induction increased at 14 days of exposure, especially at the higher temperature. At $28{ }^{\circ} \mathrm{C}, \mathrm{Cu}$ bioaccumulation was significantly lower than at 10 and $20{ }^{\circ} \mathrm{C}$ in $" \mathrm{Cu}+$ cocktail $^{\prime \prime}$ condition. Bioaccumulation was also lower for the same temperature in the presence of $\mathrm{Cu}$ alone. Therefore, at summer temperatures, in the presence of cocktail and $\mathrm{Cu}$, the plants are probably in metabolic distress and growth is minimized. All metabolic functions are maximally activated to ensure survival and bioaccumulation potential is diminished.

Auby et al. (2011) showed that herbicides from agricultural sources (and their metabolites) were more concentrated in the zone of influence of the Leyre river, in the eastern part of 
Arcachon bay. Indeed, from a spatial point of view, pesticide concentrations measured in the bay are generally more important in the east, due to dilution caused by ocean water in the west (Auby et al. 2011). In the eastern part near the Leyre river outlet pesticide concentrations of 800 to $1500 \mathrm{ng} . \mathrm{L}^{-1}$ could be found according to the season. This is consistent with our field analysis where expression levels of the 9 genes indicated molecular impacts in seagrass from sites located in the eastern part of the Bay. As early as March, plants in eastern sites had a lower metabolic activity. The impacts of compounds in this part of the Bay were emphasized during May and July. Indeed, all functions studied were overexpressed, suggesting that $Z$. noltei in Estey tort and Matoucail faced adverse effects and responded to them. Finally, results in the field were clearly consistent with experimental results, both suggesting that pesticides and $\mathrm{Cu}$ could probably be involved in the seagrass decline observed in Arcachon Bay.

\section{V - Conclusions}

This study showed that pesticides and $\mathrm{Cu}$ can impact dwarf eelgrass by adversely effecting mitochondrial metabolism and photosynthetic activities involved in energy production. Results in experimental conditions were confirmed by field analysis. Plants harvested in the eastern part of Arcachon Bay, near the Leyre river outlet, showed molecular impacts likely due to chemical compounds (pesticides, $\mathrm{Cu}$ ). This study also highlighted the effectiveness of biomarkers, such as expression levels of target genes, to determine the health status of $Z$. nolte $i$, supporting the use of seagrass health as a bioindicator of tidal ecosystem quality (Waycott, 2009; Auby et al. 2010).

\section{Acknowledgements}

The authors thank the Aquitaine Region (OSQUAR Project) for its financial support. This work was part of the OSQUAR project (oyster farming and water quality: dynamic approach in Arcachon Bay). This study was carried out in the framework of the Cluster of Excellence COTE "Continental To coastal Ecosystems: evolution, adaptability and gouvernance" (ANR$10-\mathrm{LABX}-45)$. 


\section{References}

Auby I., Maurer D. (2004) Etude de la reproduction de l'huître creuse dans le Bassin d'Arcachon. Rapport final. Rapport Ifremer R.INT.DEL/AR/04.05, 203 p+ annexes.

Auby I., Bocquené G., Quiniou F., Dreno J.P. (2007) Etat de la contamination du Bassin d'Arcachon par les insecticides et les herbicides sur la période 2005-2006. Impact environnemental. RST/LER/AR/07.003, 33 p.

Auby I., Oger-Jeanneret H., Sauriau P.G., Hily C., Barillé L. (2010) Angiospermes des côtes françaises Manche-Atlantique. Propositions pour un indicateur DCE et premières estimations de la qualité. Rapport Ifremer RST/LER/MPL/10-15, 72 p + annexes.

Auby I., Bost C.-A., Budzinski H., Dalloyau S., Desternes A., Belles A., Trut G., Plus M., Pere C., Couzi L., Feigne C., Steinmetz J. (2011) Régression des herbiers de zostères dans le Bassin d'Arcachon : état des lieux et recherche des causes. Rapport Ifremer, RST/LER/AR/11.007, 155 p.

Auby, I., \& Labourg, P. J. (1996). Seasonal dynamics of Zostera noltii Hornem. in the bay of Arcachon (France). J. Sea Res, 35(4), 269-277.

Boström C., Dromph K., Nielsen S.L., Olesen B., Olsen J., Pihl L., Rinde E. (2014). Distribution, structure and function of Nordic eelgrass (Zostera marina) ecosystems: implications for coastal management and conservation. Aquat Conserv. 24(3):410-434.

Briat J.F., Lebrun M. (1998) Plant responses to metal toxicity, Plant Biol and pathol: 43-54

Budzinski H., Tapie N., Belles A. (2010) REPAR, Action 2: Quantification de la présence Résultats des analyses chimiques sur les prélèvements ponctuels, $15 \mathrm{p}$

Cook C.M, A Kostidou, E Vardaka \& T Lanaras (1997) Effects of copper on the growth, photosynthesis and nutrient concentrations of Phaseolus plants. Photosynthetica $34,179-193$ 
Diepens N. J., Buffan-Dubau E. , Budzinski H., Kallerhoff J., Merlina G., Silvestre J., Auby I., Tapie N., Elger A.. (2017). Toxicity effects of an environmental realistic herbicide mixture on the seagrass Zostera noltei. Environ. Poll. 222 ; 393-403

Droppa M., Terry N, Horvath G. (1984) Variation in photosynthetic pigments and plastoquinone contents in sugar beet chloroplasts with changes in leaf copper content, Plant Physiology 74 : 717-720

Duarte C.M, Larkum A.W.D., Orth R.J. \& (Eds) (2006) Seagrasses: Biology, Ecology and Conservation, Marine Ecology 27: 431-432

Fleming C.A. et Trevors J.T. (1989) Copper toxicity and chemistry in the environment: a review. Water, air and soil Poll 44: 143-158

Gandar A., Jean S., Canal J., Marty-Gasset N., Gilbert F. \& Laffaille P. (2016) Multistress effects on goldfish (Carassius auratus) behavior and metabolism. Environ Sci Pollut Res Int. 23: 3184-94

Ganthy F., Soissons L., Sauriau P. G., Verney R., \& Sottolichio A. (2015). Effects of short flexible seagrass Zostera noltei on flow, erosion and deposition processes determined using flume experiments. Sedimentology, 62(4), 997-1023.

Gomes M..P, Da Silva Cruz F.V., Bicalho E.M., Borges F.V., Fonseca M.B., Juneau P., Garcia Q.S. (2017). Effects of glyphosate acid and the glyphosate-commercial formulation (Roundup) on Dimorphandra wilsonii seed germination: Interference of seed respiratory metabolism. Environ Poll. 220:452-459.

Gordon C.J. (2003) Role of environmental stress in the physiological response to chemical toxicants, Environ Res 92: 1-7

Govers L.L., Lamers L.P., Bouma T.J., Eygensteyn J., de Brouwer J.H., Hendriks A.J., Huijbers C.M., van Katwijk M.M. (2014). Seagrasses as indicators for coastal trace 
metal pollution: a global meta-analysis serving as a benchmark, and a Caribbean case study. Environ Poll. 195:210-217.

Hall J.L (2002) Cellular mechanisms for heavy metal detoxification and tolerance, J. Exp Bot 53: $1-11$

Hily C. (2004) Fiche de synthèse sur les biocénoses : Les herbiers de Zostères marines (Zostera marina et Zostera notlii), $6 \mathrm{p}$. fiche technique REBENT $\mathrm{n}^{\circ} 4$. www.rebent.org/medias/documents/www/contenu/documents/FT04-2004-01.pdf

Kuo, J., den Hartog, C. (2006). Seagrass morphology, anatomy, and ultrastructure, in: Larkum, A.W.D. et al. (Ed.) Springer: Dordrecht. Seagrasses: biology, ecology and conservation. pp. 51-87

Lee K.S., Park S.R., Kim Y.K. (2007) Effects of irradiance, temperature, and nutrients on growth dynamics of seagrasses: A review. J.Exp. Mar. Biol. and Ecol. 350: 144-175

Lewis M.A., Devereux R. (2009). Nonnutrient anthropogenic chemicals in seagrass ecosystems: fate and effects. Environ Toxicol Chem. 28: 644-661.

Livak K.J., Schmittgen T.D. (2001) Analysis of relative gene expression data using real-time quantitative PCR and the 2(T) (-Delta Delta C) method. Methods 25, 402-408

McCloskey R.M., Unsworth R.K. (2015). Decreasing seagrass density negatively influences associated fauna. PeerJ. Jun 23;3:e1053. doi: 10.7717/peerj.1053.

Moisset S., Kim Tiam S., Feurtet-Mazel A., Morin S., Delmas F., Mazzella N. and Gonzalez P. (2015) Contrasted genetic responses of three freshwater diatoms under realistic exposures of diuron. Env. Sci. and Poll. Res. 22:4046-55.

Patsikka E., Marja K., Frantisek S., Aro E.M., and Tyystjarvi E. (2002) Excess Copper Predisposes Photosystem II to Photoinhibition in Vivo by Outcompeting Iron and Causing Decrease in Leaf Chlorophyll1, Plant Physiology 129 : 1359-1367 
Plus M. (2001) Étude et modélisation des populations de macrophytes dans la lagune de Thau (Hérault, France). PhD Thesis, Paris 6, 1-107

Plus M., Dalloyau S., Trut G., Auby I., De Montaudouin X., Emery E., Noel C., Viala C. (2010). Long-term evolution (1988-2008) of Zostera spp. meadows in Arcachon Bay (Bay of Biscay). Estuar Coast And Shelf Sci, 87(2), 357-366

Prange J.A., Dennison W.C. (2000) Physiological responses of five seagrass species to trace metals, Mar poll bull 41: 327-336

Mohanty N., Vass I., Demeter S. (1989) Copper toxicity affects photosystem II electron transport at the secondary quinone acceptor, QB. Plant Physiol 90: 175-179

Rauser W. (1995) Phytochelatins and related peptides, Plant Physiol. 109: 1141-1149

Ribaudo C. (2006) Étude de la croissance et des caractéristiques structurelles de Zostera noltii dans le Bassin d'Arcachon. Rapport de stage, Universita'degli studi di parma, programme Leonardo da Vinci., 31p.

Ribaudo, C., Ganthy, F., and Auby, I. (2016). Carbon sequestration loss following Zostera noltei decline in the Arcachon Bay (France). Estuar Coast and Shelf Sci, 179, 4-11.

Sako A., Kandakar J., Tamari N., Higa A., Yamaguchi K., Kitamura Y. (2016). Copper excess promotes propagation and induces proteomic change in root cultures of Hyoscyamus albus L. Plant Physiol Biochem. 103:1-9.

Teisseire H., Couderechet M., Vernet G. (1999) Phytotoxicity of diuron alone and in combination with copper or folpet on duckweed (Lemna minor), Environ Poll 106: 3945

Thursby G. B., Harlin M. M. (1984) Interactions of leaves and roots of Ruppia maritime in the uptake of phosphate, ammonium and nitrate. Mar Biol 83: (p 61-67) 
Turrens J.F. (1997) Superoxide production by the mitochondrial respiratory chain. Biosciences Rep.17, 3-8.

Vermaat J.E., Hootsmans M.J.M., Nienhuis P.H. (1987) Seasonal dynamics and leaf growth of Zostera noltii Hornem, a perennial intertidal seagrass. Aqua Bot 28: 287-285

Waycott M., Duarte M., Carruthers T.J.B., Orth R.J., Dennison W.C., Olyarnik S., Calladine A., Fourqurean J.W., Heck K.L., Hughes A.R., Kendrick G.A., Kenworthy W.J., Short F.T. ,Williams S.L. (2009) Accelerating loss of seagrasses across the globe threatens coastal ecosystems. Proc Natl Acad Sci USA 12377-12381

Zevenhuizen, L. R T. M., Dolfing, J., Eshuis, E. J., and Scholten-Koerselman, I. J. (1979) Inhibitory effects of copper on bacteria related to the free ion concentration, Microb Ecol 5: 139-146

Zieman J.C. (1974) Methods for the study of the growth and production of the turtlegrass, Thalassia testudinum König. Aquaculture, 4: 139-143 
Table I: List and concentrations of compounds in the cocktail of pesticides in the initially solution introduced and the intermediate solution. OA = Oxanilic Acid. ESA = EthaneSulfonic Acid

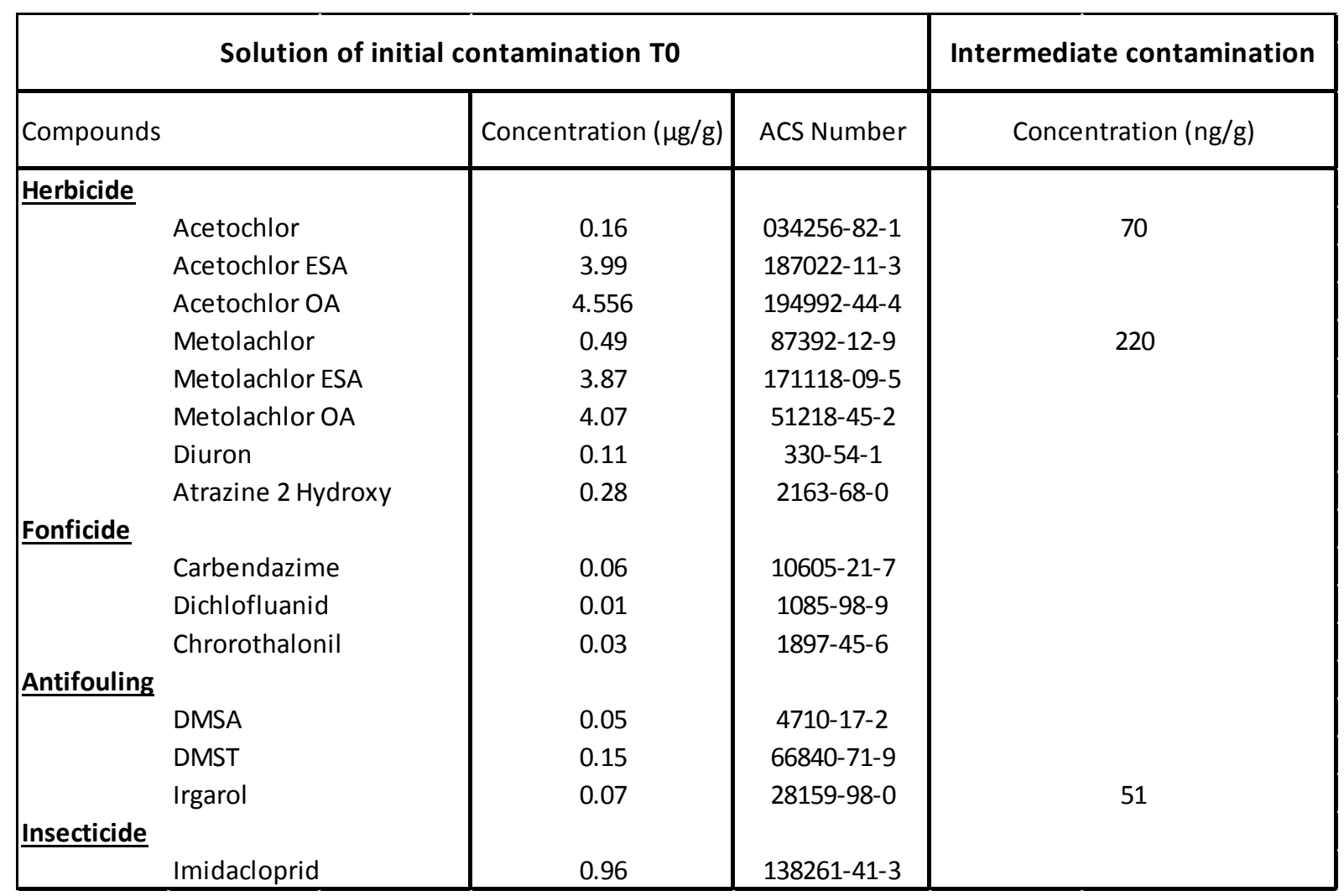


Table II: Specific Primer-pairs

\begin{tabular}{|c|c|}
\hline Gene name & Primers \\
\hline$\beta$ actin & $\begin{array}{l}\text { GTGGCACCTGAAGAACATCC }^{\mathrm{a}} \\
\text { ACCATCACCTGAACCAAGC }^{\mathrm{a}}\end{array}$ \\
\hline sodMn & $\begin{array}{l}\text { ACCACCGGGCCTATGT }^{\mathrm{a}} \\
\text { GTGTCGATAGCCCATCCTAGT }^{\mathrm{b}}\end{array}$ \\
\hline cat & $\begin{array}{l}\text { AAGGGGTTCTTTGAGGTCAC }^{\mathrm{a}} \\
\text { CGAGCAGGGTCATACCTTG }^{\mathrm{b}}\end{array}$ \\
\hline gpx & $\begin{array}{l}\text { CGATTTCACCGTTAAGGATGCC }^{\mathrm{a}} \\
\text { GGCTCCTGCCCTCCAA }^{\mathrm{b}}\end{array}$ \\
\hline $\operatorname{cox} 1$ & $\begin{array}{l}\text { GCCACCAAGTCTCTTGCT }^{\mathrm{a}} \\
\text { CCAGGTCCACGCATGT }^{\mathrm{b}}\end{array}$ \\
\hline nad5 & $\begin{array}{l}\text { GCAAGATATGCGGAAGATGGG }^{\mathrm{a}} \\
\text { AGAGTAATAAGAAGTGAAAAGGACAGAG }^{\mathrm{b}}\end{array}$ \\
\hline $12 S$ & $\begin{array}{l}\text { AGCACGTAGGCAGTTCAT }^{\mathrm{a}} \\
\text { GCACCTCAGCGTCGGTAG }^{\mathrm{b}}\end{array}$ \\
\hline$d 1$ & $\begin{array}{l}\text { AATAGGGAGCCGCCGA }^{\mathrm{a}} \\
\text { GCGTCCTTGGATTGCTGT }^{\mathrm{b}}\end{array}$ \\
\hline$\overline{p s a A}$ & $\begin{array}{l}\text { GTTTAACTTGGGGAGGCGG }^{\mathrm{a}} \\
\text { CCCCTCTTCCAGGTCCAT }^{\mathrm{b}}\end{array}$ \\
\hline
\end{tabular}

a: forward, b : reverse

Table III: Basal expression in Z. noltii observed in the leaves at 7 and 14 days for the three temperatures

\begin{tabular}{|c|c|c|c|c|c|c|c|}
\hline \multirow{3}{*}{ Functions } & \multirow[t]{3}{*}{ Genes } & \multicolumn{6}{|c|}{ Experimental units contaminated } \\
\hline & & \multicolumn{3}{|c|}{ Control T7 } & \multicolumn{3}{|c|}{ Control T14 } \\
\hline & & $10^{\circ} \mathrm{C}$ & $20^{\circ} \mathrm{C}$ & $28^{\circ} \mathrm{C}$ & $10^{\circ} \mathrm{C}$ & $20^{\circ} \mathrm{C}$ & $28^{\circ} \mathrm{C}$ \\
\hline \multirow{3}{*}{$\begin{array}{l}\text { Mitochondrial } \\
\text { metabolism }\end{array}$} & $\operatorname{cox} 1$ & 5.9 & 2.5 & 0.8 & 0.9 & 8 & $\mathbf{0 . 0 1}$ \\
\hline & nad5 & 0.4 & 0.1 & $\mathbf{0 . 0 2}$ & 0.03 & 0.1 & 0.007 \\
\hline & $12 \mathrm{~s}$ & 58 & 22 & 6 & 4 & 30 & 3.4 \\
\hline \multirow[t]{3}{*}{ Oxidative stress } & sodMn & 1 & 0.1 & 6 & 0.6 & 1.4 & $\mathbf{0 . 0 2}$ \\
\hline & cat & $\mathbf{0 . 0 7}$ & 0.1 & 0.1 & 0.05 & 0.2 & 0.01 \\
\hline & $g p \times 1$ & 1.5 & 0.1 & 1.4 & 1 & 3 & 0.2 \\
\hline \multirow[t]{2}{*}{ Photosynthesis } & $d 1$ & 31 & 56 & 1.8 & 3 & 43 & 1.1 \\
\hline & $p s a A$ & 5.7 & 0.5 & 1 & 0.9 & 0.8 & 0.04 \\
\hline
\end{tabular}

Black and fat: significant decrease / Black and italic: significant increase 
Table IV: Differential Gene Expression in Zostera noltii observed in leaves after exposure to copper, cocktail of pesticides used alone or mixed at 7 and 14 days.

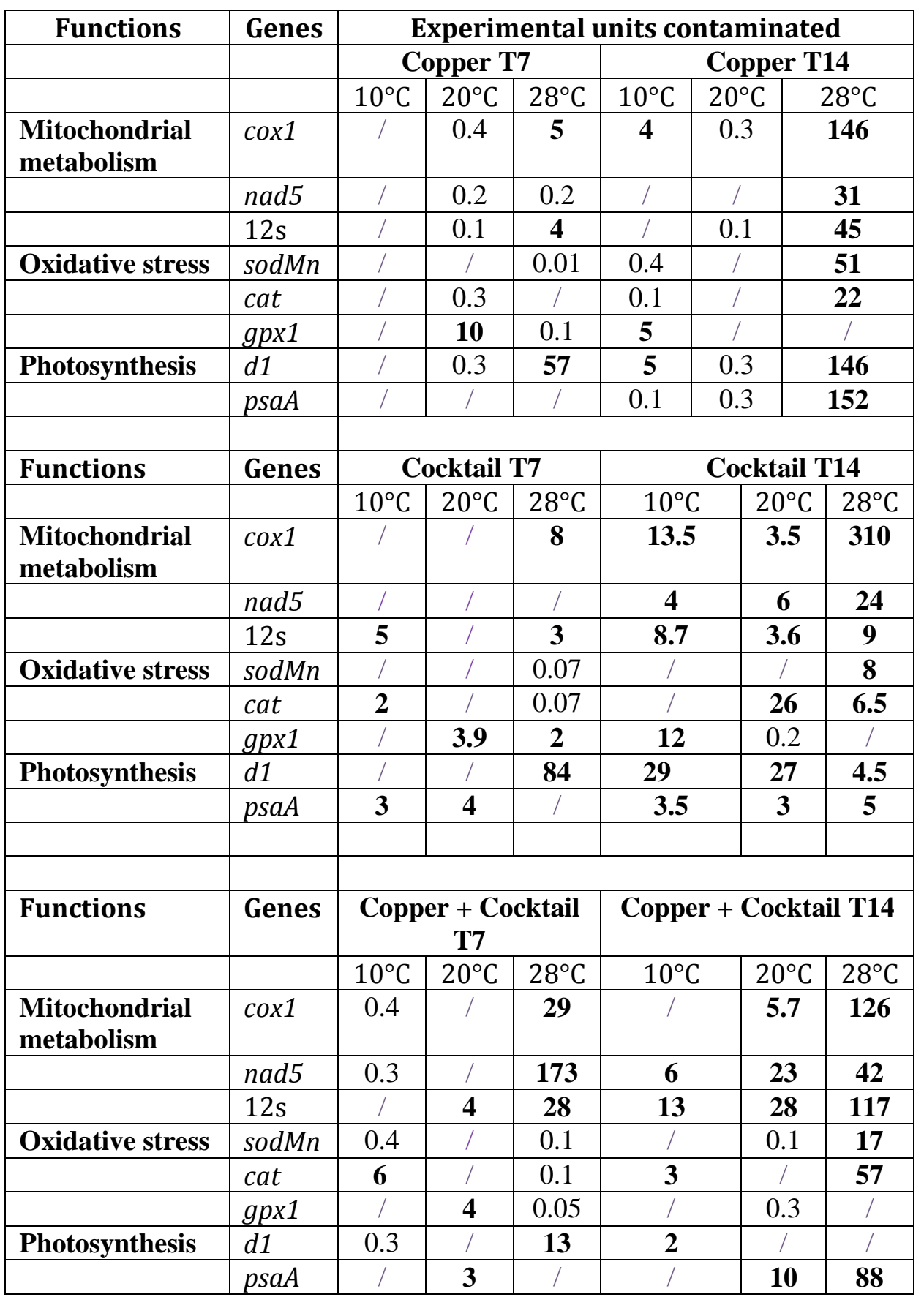

The results are expressed as induction factors $(>2)$ or repression $(<1 / 2)$ compared to control. /: Identical to the control. 
Table V: Differential expression observed in Z. noltei leaves from Haubelle, Estey tort and Matoucail compared to Afrique.

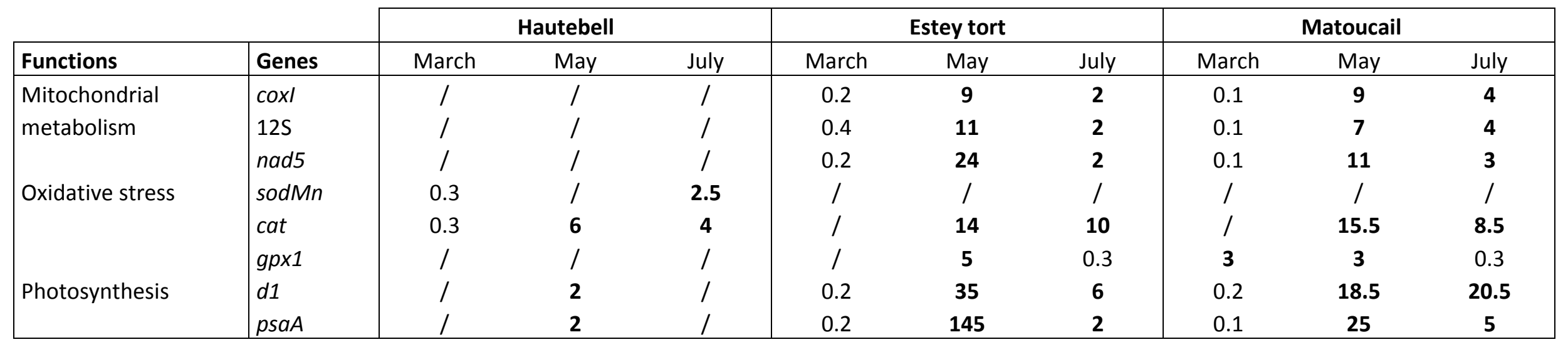

Results are expressed as overexpressed (>2) or decrease $(<0.5)$. /: identical to expression observed in Afrique 


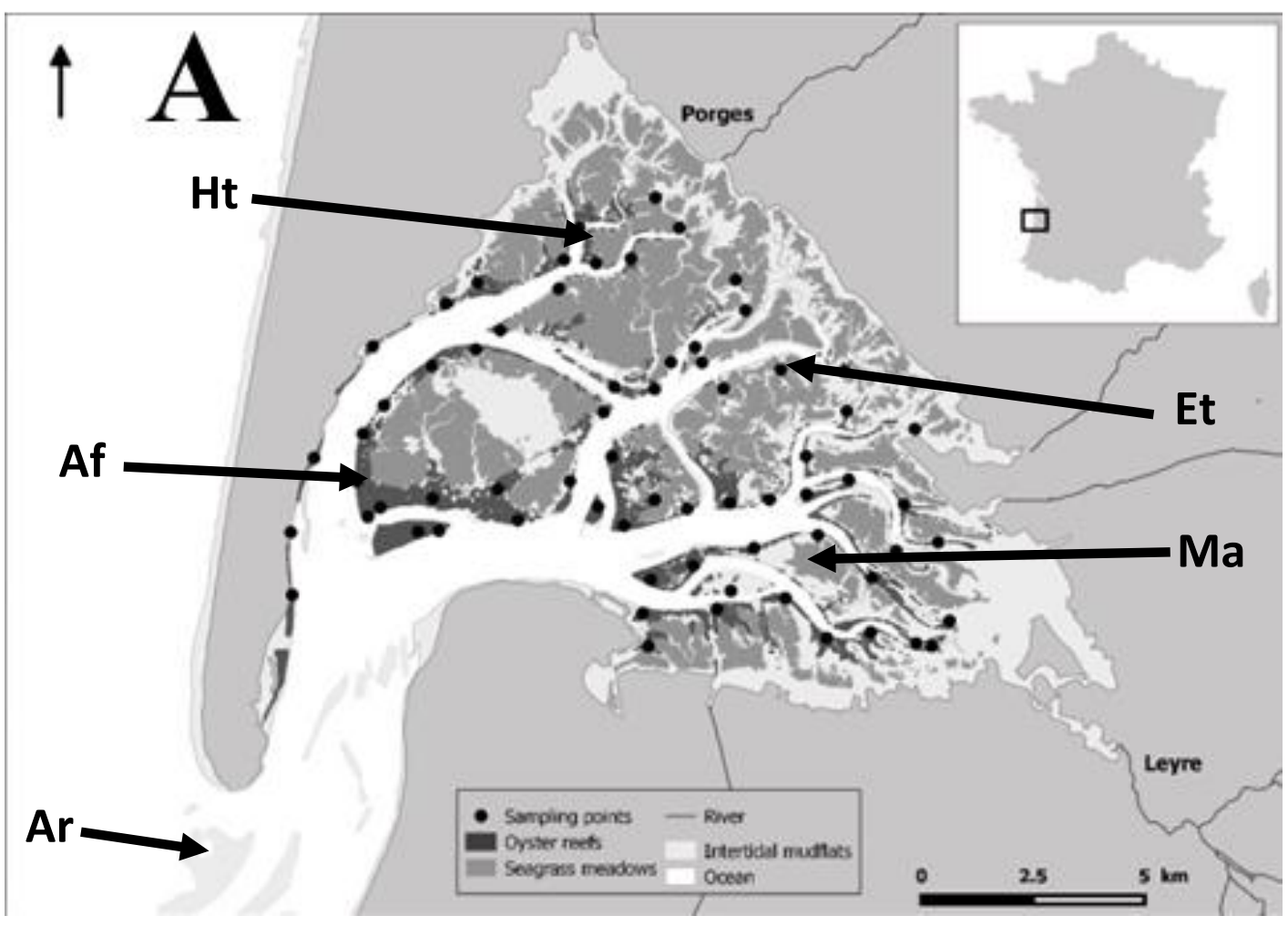

Figure 1; Location of the 4 sites used during the field survey within the Arcachon Bay( Af; Afrique, Ht; Hautebelle, Et; Estey tort, Ma; Matoucail) and of the harvesting site for plants used in the experimental approach (Ar; Arguin). 


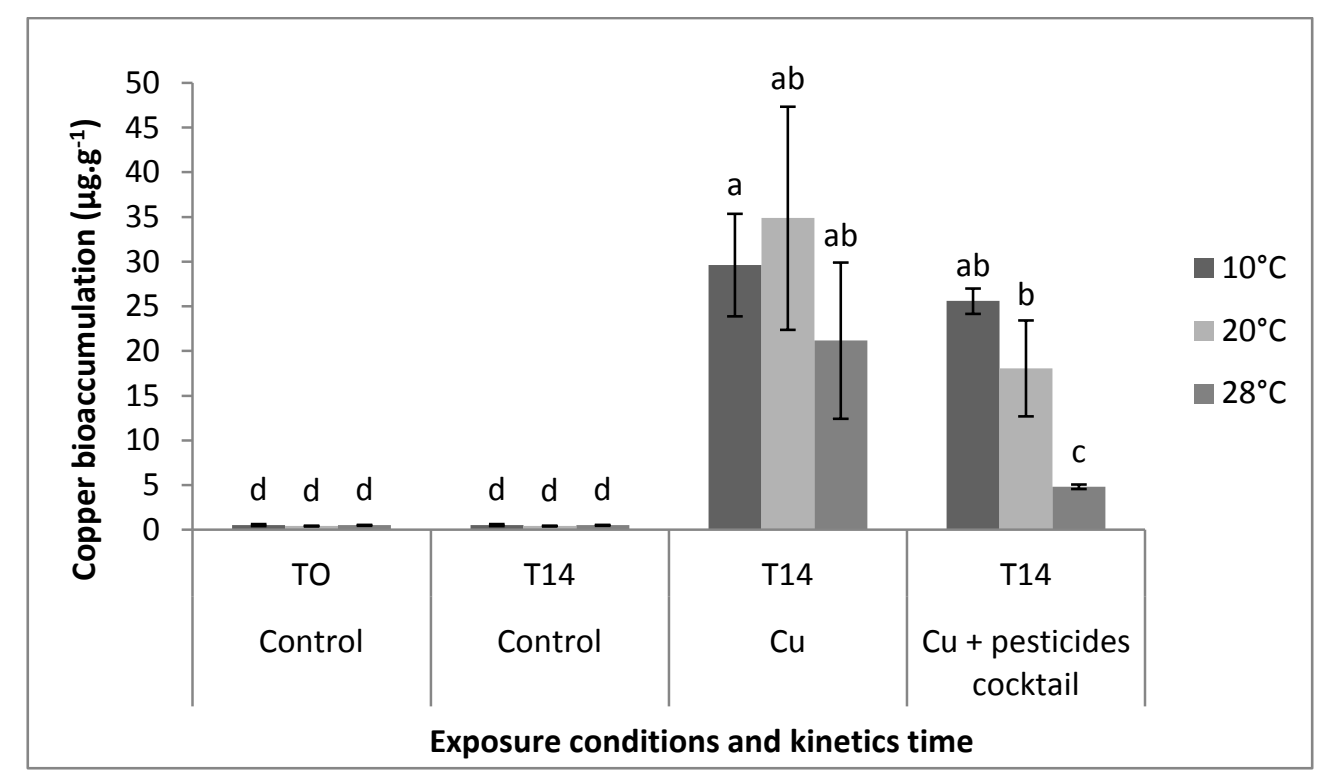

Figure 2; $\mathrm{Cu}$ bioaccumulation in the leaves of eelgrasses (Mean $\pm \mathrm{SD}$ ) according to the temperature and exposure conditions at T0 and T14. Different letters indicated significant differences between different temperature and time exposure $(\mathrm{p}<0.05)$

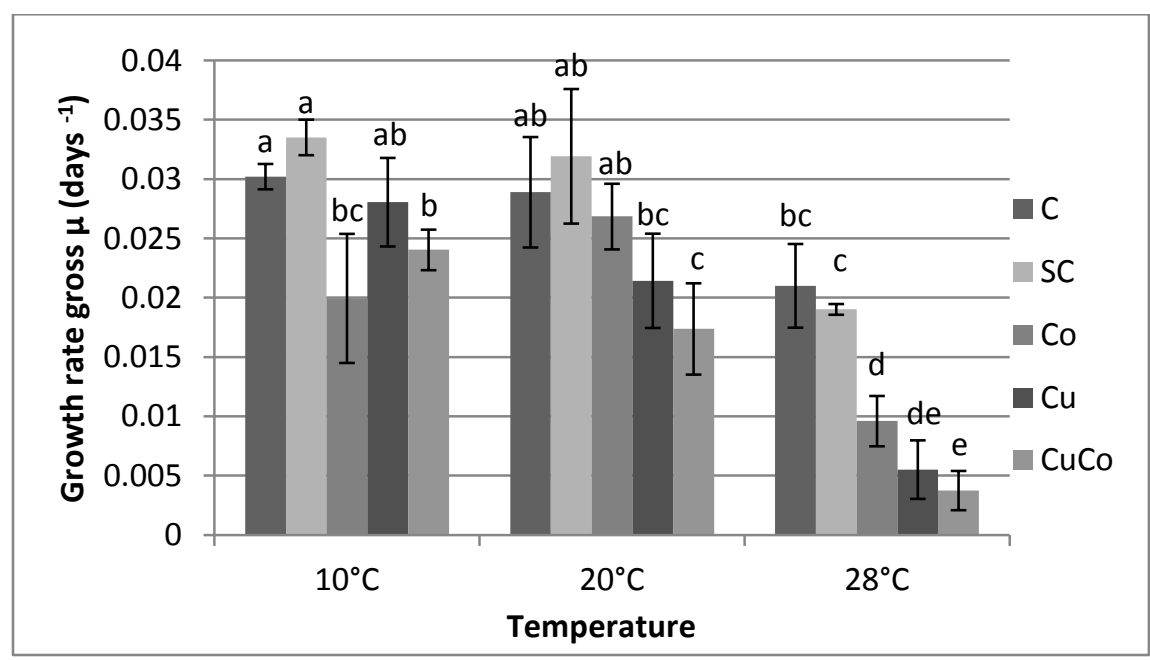

Figure 3; Growth rate gross of eelgrasses leaves (Mean $\pm \mathrm{SD}$ ) according to the temperature $\left(10^{\circ} \mathrm{C}, 20^{\circ} \mathrm{C}, 28^{\circ} \mathrm{C}\right)$ and exposure conditions (C : control, SC: solvent control, Co: cocktail of pesticides, $\mathrm{Cu}$ : copper and $\mathrm{CuCo}$ : copper and cocktail of pesticides associated). Different letters indicated significant differences between different temperature and condition exposure $(\mathrm{p}<0.05)$ 

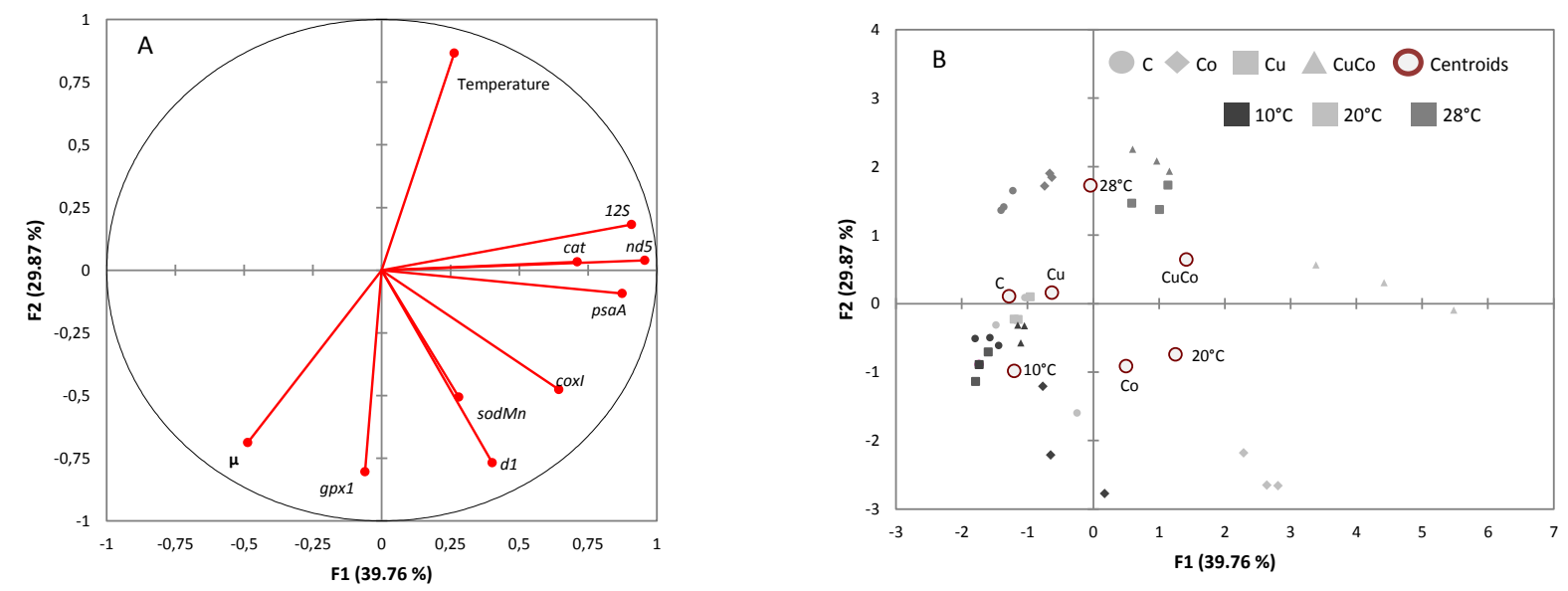

Figure 4: Principal component analysis (PCA): (A) Relationships between the transcription level of genes, growth rate gross $(\mu)$ and temperature in eelgrasses leaves after 14 days of experimental exposure. Percentage of total inertia explained for the principal components 1 and 2 were $39.76 \%$ and $29.87 \%$ respectively. (B) Screening of eelgrasses according to the temperature $\left(10{ }^{\circ} \mathrm{C}, 20{ }^{\circ} \mathrm{C}, 28{ }^{\circ} \mathrm{C}\right)$ and experimental exposure conditions (C : control (cercles), Co: cocktail of pesticides (diamonds), $\mathrm{Cu}$ : copper (squares) and $\mathrm{CuCo}$ : copper and cocktail of pesticides associated (triangles)) on the principal component 1 and 2. 